\title{
Parameters Analysis for Bending Properties of Externally Prestressed Concrete Beam with Corrugated Steel Webs
}

\author{
Qiang $\mathrm{Xu}^{1}$, Jianyong Song ${ }^{1}$, Jianxiang Feng ${ }^{2}$ and Jinsheng $\mathrm{Du}^{2}$ \\ ${ }^{1}$ Bridge technology research center, Research Institute of Highway Ministry of Transport, Beijing, China \\ ${ }^{2}$ Department of Bridge engineering, Beijing Jiaotong University, Beijing, China
}

\begin{abstract}
Based on the bending moment-curvature method, a calculation program for the whole bending process of externally prestressed concrete beam with corrugated steel webs is compiled and parametric analysis is conducted. Considering the nonlinearity of material, this procedure can calculate the whole bending process of externally prestressed composite beam with corrugated steel webs under different load, cross section, and external tendons profiles and output the cross section strain of concrete and ordinary reinforcements, stress increment of external prestressing tendons and mid-span deflection. The results show that the tension steel area has the greatest impact on the bending performance of simply supported externally prestressed composite beam with corrugated steel webs; The second is concrete strength and effective external prestress; The compression steel area has limited impact on the bending performance of such beams. The results can provide a reference for design of the beam.
\end{abstract}

\section{Introduction}

In prestressed concrete $(\mathrm{PC})$ bridges with corrugated steel webs, the steel webs mainly resist shear while the flanges mainly resist bending. Their advantages include lightness and high shear buckling strength of steel webs, efficient prestressing of concrete and easy maintenance. The appearance of Cognac Bridge of this type in France has prompted research and development efforts in various countries on this new composite structure [1]-[4]. Currently, many investigations have been done on such beam's ultimate capacities, stress distribution, failure mechanism, while few have addressed the factors that may influence the bending behavior of the beam [5]-[7]. In this paper, based on the moment-curvature method, a nonlinear full process program is established for externally PC beams with corrugated steel webs. By using this numerical program, parametric analysis is conducted to further investigate the factors that may affect the bending performance of the beam.

\section{Calculation program}

\subsection{Calculation assumption}

In the program, some assumptions as follow are adopted: Plane sections remain plane; The flexural rigidity of corrugated steel webs is negligible [8]-[10]; The corrugated steel webs with sufficient buckling strength, will not happen any form of buckling failure; With sufficient shearing strength, the beam only happens bending failure; Stress evenly distributed along externally prestress tendons; After cracking, the contribution of concrete in tension zone is negligible; The beam is incompressible vertically.

\subsection{Material constitutive model}

In the program, the following materials constitutions are adopted: The Rüsch equation is adopted to describe the unidirectional compression constitution of concrete, and the ultimate compressive strain of concrete is taken as 0.003 . The ideal elastic-plastic model is used as the constitution of reinforcement steel, and the steel plate and the ultimate strain of the steel is taken as 0.01.The constitution of the externally prestressed tendons is given by:

$$
\left\{\begin{array}{ccc}
\sigma_{p}=E_{p} \varepsilon_{p} & \text { for } & \varepsilon_{p} \leq f_{p y} / E_{p} \\
\sigma_{p}=f_{p y}+0.3 E_{p}\left(\varepsilon_{p}-f_{p y} / E_{p}\right) & \text { for } & \varepsilon_{p}>f_{p y} / E_{p}
\end{array}\right.
$$

where, $\sigma_{p}$ is the stress in prestressed tendons; $E_{p}$ is the elastic modulus of prestress tendons; $\varepsilon_{p}$ is the strain in prestress tendons; $f_{p y}$ is the yield strength of prestress tendons.

\subsection{Cross-section balance equation}

For any cross-section of the beam, we can always get the following equations:

$$
\varepsilon_{y}=\left\{\begin{array}{ll}
\varphi(y+c-h) & \text { for } \varphi \geq 0 \\
\varphi(c-y) & \text { for } \varphi<0
\end{array} .\right.
$$




$$
\begin{aligned}
& N_{c}+N_{t}+\sigma_{s} A_{s}+\sigma_{g} A_{g}+\sigma_{s}^{\prime} A_{s}^{\prime}+\sigma_{p} A_{p}=0 . \\
& M+M_{c}+M_{t}+\sigma_{s}^{\prime} A_{s}^{\prime}\left(y_{x}-a_{s}^{\prime}\right)-\sigma_{s} A_{s}\left(y_{x}-a_{s}\right) \\
& +\sigma_{g}^{\prime} A_{g}^{\prime}\left(y_{s}-a_{g}^{\prime}\right)+\sigma_{g} A_{g}\left(y_{x}-a_{g}\right)+\sigma_{p} A_{p} y_{p}=0
\end{aligned} .
$$

where, $M$ is the total applied bending moment; $N_{c}$ is the sum of concrete stress in compressive zone; $M_{c}$ is the sum of bending moment of concrete stress in compressive zone about the centroidal axis of cross-sections; $N_{t}$ is the sum of concrete stress in tensile zone; $M_{t}$ is the sum of bending moment of concrete stress in tensile zone about the centroidal axis of cross-sections; The geometrical characteristic of cross-section is shown in Figure 1.

With (2), (3) and (4), if the stress increments of externally prestress tendons $\Delta \sigma_{p}$ are known, $\varphi$ and $c$ can be obtained.

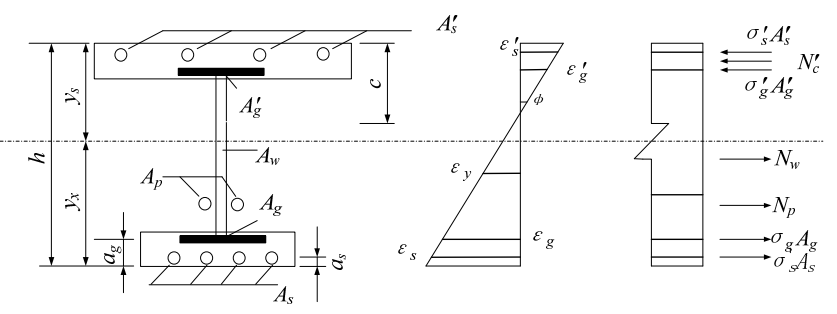

Fig. 1. Stress-strain relationship at a cross section.

\subsection{Calculation of stress increments of externally prestressed tendons $\Delta \sigma_{p}$}

The length increments of externally prestressed tendons $\Delta L_{p}$ have to respect compatibility with the deformation of the beam. Taking a beam of straight tendons with anchorages at the end diaphragms and one intermediate diaphragm as deviators for example, which is shown in Figure 2, $\Delta L_{p}$ can be expressed as:

$$
\Delta L_{p}=\sqrt{f_{c}^{2}+\left(\frac{1}{2} L+\mu_{C}-\theta_{A} \cdot y_{p}^{A}\right)^{2}}+\sqrt{f_{c}^{2}+\left(\frac{1}{2} L+\mu_{B}+\theta_{B} \cdot y_{p}^{B}-\mu_{C}\right)^{2}}-L
$$

and $\Delta \sigma_{p}$ can be expressed as:

$$
\Delta \sigma_{p}=E_{p} \frac{\Delta L_{p}}{L_{p}}-\sigma_{p e}
$$

where, $f_{c}$ is the deflection of intermediate deviator location $C ; L$ is the span of the beam; $\theta_{A}, \theta_{B}$ is the rotation angles at the anchorage locations $A$ and $B$, respectively; $\mu_{B}, \mu_{C}$ is the axial deformation at the anchorage location $\mathrm{B}$ and intermediate deviator location $C$, respectively; $L_{p}$ is initial length of the prestressed tendons; $\sigma_{p e}$ is the initial stress of the prestressed tendons; $y_{p}^{A}$ and $y_{p}^{\mathrm{B}}$ is the distance from centroidal level to anchorage locations $A$ and anchorage locations $B$, respectively; $f_{c}$, $\theta_{A}, \theta_{B}$ can be obtained by using the principle of virtual work; , $\mu_{B}, \mu_{C}$ can be calculated through the integration of strain in cross-sections.

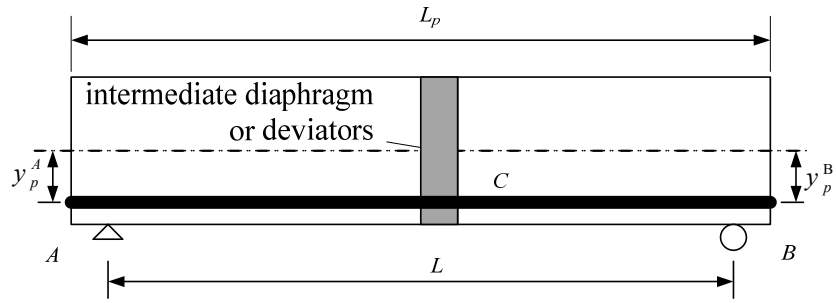

Fig. 2. A beam with straight profiled tendons.

\subsection{Calculation method and process}

At the beginning of the calculation program, the beam is discretized into $n$ small elements along the axial direction of the beam and assuming that within any element. All of the cross-sections have the same compressive zone height $\mathrm{c}$ and curvature $\varphi$. Then giving stress increments of externally prestressed tendons $\Delta \sigma_{p}^{\prime}$, with (2), (3) and (4), $c$ and $\varphi$ of any cross-section can be obtained, also the displacements of the locations of the anchorage and deviators, through strain integration and the principle of virtual work. Hereafter, $\Delta L_{p}$ and $\Delta \sigma_{p}$ can be calculated by using (5) and (6). $\Delta \sigma_{p}$ and $\Delta \sigma_{p}^{\prime}$ will then be compared for iteration until they are close to each other.

Considering material nonlinearity, the all-stage mechanical behavior of simple supported externally PC beam with corrugated steel webs can be calculated by using the nonlinear all-stage-analysis program. Taking account of different loading conditions, external tendons profiles and cross-section shapes, the program can calculate not only the stress and strain in concrete, reinforcement steels and prestressed tendons but also the deflection of the beam for all loading stages from start to failure.

\section{Verification of the program}

To show the efficiency and the reliability of the program proposed, the program calculated results of one existing experimental beam are compared with its experimental results.

The experimental beam [11], with I-section and single $4 \mathrm{~mm}$ thick corrugated steel web, is $400 \mathrm{~mm}$ in depth and simply supported over a span of $3000 \mathrm{~mm}$. It is posttensioned externally by two $\Phi^{s} 15.24$ steel tendons with straight profile and draped at two symmetrically placed deviators at the third-point. The anchorages and two intermediate diaphragm or deviators of the specimen are located $100 \mathrm{~mm}$ above the soffit. It is subjected to thirdpoint loading. The initial effective prestress of external tendons is $645.9 \mathrm{MPa}$. Both of the thicknesses of the top concrete flange and bottom concrete flange are $70 \mathrm{~mm}$. The material properties are shown in Table 1.

The all-stage curves of load vs. deflection and load vs. external tendon stress are compared with the numerical results in Figure 3 and 4 respectively, showing reasonable agreement. Despite some discrepancy, the calculation results capture the trend of the evolution of external 
tendon force and mid-span deflection well. The ratio of the program calculated ultimate load with its measured value is 0.92 . The ratio of the program calculated ultimate mid-span deflection with its measured value is 0.94 . The ratio of the program calculated ultimate external tendon stress increments with its measured value is 0.93 . The discrepancy between the program calculated values and the measured is within $10 \%$.

Table 1. Material properties of experimental beam of Harbin Industrial University (unit: MPa).

\begin{tabular}{|c|c|c|c|c|}
\hline & Concrete & $\begin{array}{c}\text { External } \\
\text { tendons }\end{array}$ & $\begin{array}{c}\text { Reinforcement } \\
\text { steels }\end{array}$ & $\begin{array}{c}\text { Steel } \\
\text { web }\end{array}$ \\
\hline $\begin{array}{c}\text { Young's } \\
\text { modulus(MPa) }\end{array}$ & 31736 & 196000 & 210000 & 205000 \\
\hline $\begin{array}{c}\text { Yield } \\
\text { strength(MPa) }\end{array}$ & - & - & 330 & 315 \\
\hline $\begin{array}{c}\text { Ultimate } \\
\text { strength(MPa) }\end{array}$ & $34.7($ cube) & 1860 & - & - \\
\hline
\end{tabular}

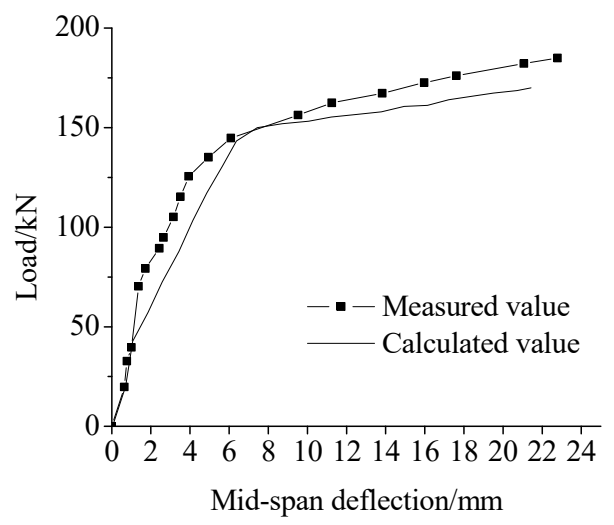

Fig. 3. Measured and calculated mid-span deflection.

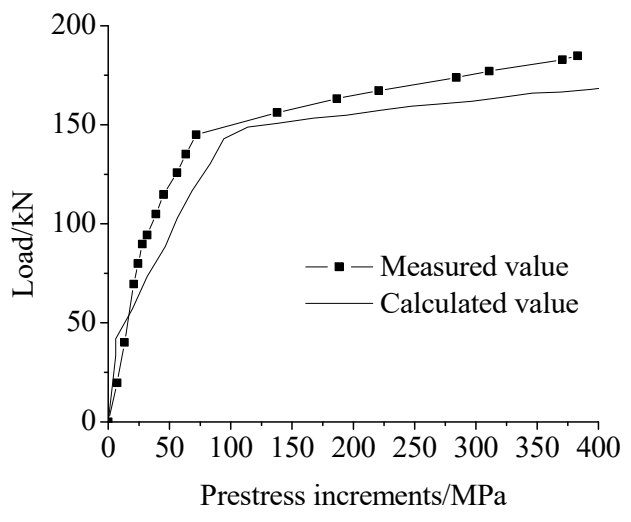

Fig. 4. Measured and calculated stress increments.

\section{Parameters analysis}

With HIT(Harbin Industrial University) test beam being beam A, varying someone parameter of beam A and keeping other parameters unchanged, beams with different parameters will be got. All of these beams will be calculated to study the influence of important parameters to the bending performance of externally PC beam with corrugated steel webs. The parameters of beam $\mathrm{A}$ is listed in Table 2, the value of ultimate mid-span deflection and ultimate load/cracking load are amplified 10 times to their real values.

\subsection{Tension steel area}

Varying the tension steel area of beam A from $300 \mathrm{~mm} 2$ to $1500 \mathrm{~mm} 2$ and keeping other parameters unchanged, four beams named B1, B2, B3, B4 can be got and their calculated results are listed in Table 3. It can be seen from Table 3 that with the increase of tension steel area, the failure of the beam changes from tensile steel pulled off to compressive concrete crushed. The ultimate stress increments of external tendons decrease insignificant at first, then decrease sharply after a value of tension steel area, with which the beam (i.e. beam B3) has the failure of tensile steel pulled off and compressive concrete crushed simultaneously. The ultimate mid-span deflection increases insignificant at first, then reduces sharply after the tension steel area of B3. The ultimate load and the ratio of the ultimate load to the cracking load increase all along.

When tension steel area increases $100 \%$, the ultimate stress increments reduce $7 \%$ and $135 \%$ before and after the tension steel area value of B3, respectively. The ultimate mid-span deflection increases $2 \%$ before the special value and decreases $73 \%$ after the special value. Both of the ultimate load and the ratio of the ultimate load to the cracking load increase $21 \%$. The tension steel area has great influence on mechanical properties of externally PC beam with corrugated steel webs.

When tension steel area of beam A changed to the same value with beam B3 and keeping other parameters unchanged, the beam has the failure of tensile steel pulled off and compressive concrete crushed simultaneously. The ultimate mid-span deflection and the ultimate stress increments of externally tendons get to the maximum value. The performance of tensile steel and compressive concrete are both brought into full play and the beam has sufficient ductility with no brittle fracture occurring. The tensile reinforcements can improve the ductility of this beam.

Table 2. Parameters of beam A.

\begin{tabular}{|c|c|c|c|}
\hline $\begin{array}{c}\text { Tension teel } \\
\text { area } \\
(\mathrm{mm} 2)\end{array}$ & $\begin{array}{c}\text { Compression } \\
\text { teel area } \\
(\mathrm{mm} 2)\end{array}$ & $\begin{array}{c}\text { Concrete cube } \\
\text { strength } \\
(\mathrm{MPa})\end{array}$ & $\begin{array}{c}\text { Effective } \\
\text { prestress } \\
(\mathrm{MPa})\end{array}$ \\
\hline 566 & 201 & 34.7 & 645.9 \\
\hline
\end{tabular}

Table 3. Calculated values of beams with different tension steel area.

\begin{tabular}{|c|c|c|c|c|}
\hline $\begin{array}{c}\text { Name of } \\
\text { beam }\end{array}$ & $\begin{array}{c}\text { Tension teel } \\
\text { area } \\
(\mathrm{mm} 2)\end{array}$ & $\begin{array}{c}\text { Cracking } \\
\text { load } \\
(\mathrm{kN})\end{array}$ & $\begin{array}{c}\text { Ultimate load/ } \\
\text { cracking load }\end{array}$ & $\begin{array}{c}\text { Ultimate } \\
\text { Load } \\
(\mathrm{kN})\end{array}$ \\
\hline $\mathrm{B} 1$ & 300 & 32.99 & 4.35 & 143.39 \\
\hline $\mathrm{A}$ & 566 & 32.45 & 5.32 & 172.65 \\
\hline $\mathrm{B} 2$ & 700 & 32.45 & 5.76 & 186.76 \\
\hline B3 & 1270 & 32.11 & 7.63 & 245.10 \\
\hline B4 & 1500 & 31.9 & 8.07 & 264.82 \\
\hline $\begin{array}{c}\text { Name of } \\
\text { beam }\end{array}$ & $\begin{array}{c}\text { Ultimate stress } \\
\text { increments } \\
(\mathrm{MPa})\end{array}$ & $\begin{array}{c}\text { Ultimate } \\
\text { mid-span } \\
\text { deflection } \\
(\mathrm{mm})\end{array}$ & $\begin{array}{c}\text { Ultimate strain } \\
\text { of tensile } \\
\text { reinforcement }\end{array}$ & $\begin{array}{c}\text { Ultimate } \\
\text { strain of } \\
\text { top edge } \\
\text { concrete }\end{array}$ \\
\hline B1 & 447.68 & 21.68 & 0.0099 & 0.0020 \\
\hline
\end{tabular}




\begin{tabular}{|c|c|c|c|c|}
\hline A & 443.04 & 22.35 & 0.0099 & 0.0022 \\
\hline B2 & 436.97 & 22.43 & 0.0100 & 0.0023 \\
\hline B3 & 377.48 & 22.75 & 0.0100 & 0.0030 \\
\hline B4 & 285.37 & 18.93 & 0.0082 & 0.0030 \\
\hline
\end{tabular}

\subsection{Compression steel area}

Varying the compression steel area of beam A to $402 \mathrm{~mm} 2$ and $603 \mathrm{~mm} 2$ respectively and keeping other parameters unchanged, two beams named $\mathrm{C} 1, \mathrm{C} 2$ can be got and their calculated results are listed in Table 4. It can be seen from Table 4 that with the increase of tension steel area, the ultimate stress increments of external tendons and the ultimate load increase insignificant all along. The ultimate mid-span deflection keeps almost unchanged. The ratio of the ultimate load to the cracking load decreases insignificant all along.

When compression steel area increases $100 \%$, the ultimate stress increments increase $2 \%$. The ultimate load increases $5 \%$. The ratio of the ultimate load to the cracking load decreases $6 \%$. The tension steel area has limited influence on mechanical properties of externally PC beam with corrugated steel webs. The tensile reinforcements can improve the ductility of this beam.

Table 4. Calculated values of beams with different compression steel area.

\begin{tabular}{|c|c|c|c|c|}
\hline $\begin{array}{c}\text { Name of } \\
\text { beam }\end{array}$ & $\begin{array}{c}\text { Compression } \\
\text { teel area } \\
(\mathrm{mm} 2)\end{array}$ & $\begin{array}{c}\text { Cracking } \\
\text { load } \\
(\mathrm{kN})\end{array}$ & $\begin{array}{c}\text { Ultimate } \\
\text { load/ } \\
\text { cracking load }\end{array}$ & $\begin{array}{c}\text { Ultimate } \\
\text { load } \\
(\mathrm{kN})\end{array}$ \\
\hline $\mathrm{A}$ & 201 & 32.45 & 5.32 & 172.65 \\
\hline $\mathrm{C} 1$ & 402 & 41.15 & 4.61 & 189.78 \\
\hline $\mathrm{C} 2$ & 603 & 41.15 & 4.65 & 191.44 \\
\hline $\begin{array}{c}\text { Name of } \\
\text { beam }\end{array}$ & $\begin{array}{c}\text { Ultimate stress } \\
\text { increments } \\
(\mathrm{MPa})\end{array}$ & $\begin{array}{c}\text { Ultimate mid- } \\
\text { span } \\
\text { deflection } \\
(\mathrm{mm})\end{array}$ & $\begin{array}{c}\text { Ultimate } \\
\text { strain of } \\
\text { tensile } \\
\text { reinforcement }\end{array}$ & $\begin{array}{c}\text { Ultimate } \\
\text { strain of } \\
\text { top edge } \\
\text { concrete }\end{array}$ \\
\hline $\mathrm{A}$ & 443.04 & 22.35 & 0.0099 & 0.0022 \\
\hline $\mathrm{C} 1$ & 452.7 & 22.41 & 0.0010 & 0.0021 \\
\hline $\mathrm{C} 2$ & 458.51 & 22.34 & 0.0010 & 0.0016 \\
\hline
\end{tabular}

\subsection{Concrete strength}

Varying the concrete cube strength of beam A to $60 \mathrm{MPa}$ and $80 \mathrm{MPa}$ respectively and keeping other parameters unchanged, two beams named D1, D2 can be got and their calculated results are listed in Table 5. It can be seen from Table $\mathrm{V}$ that with the increase of concrete cube strength, the ultimate stress increments of external tendons and the ultimate load increase insignificant all along. The ultimate mid-span deflection keeps almost unchanged. The ratio of the ultimate load to the cracking load decreases insignificant all along.

When concrete cube strength increases $100 \%$, the ultimate stress increments increase 19\%. The ultimate mid-span deflection increases by $7 \%$. The ultimate load increases $7 \%$. The ratio of the ultimate load to the cracking load decreases $42 \%$. The tension steel area has limited influence on mechanical properties of externally PC beam with corrugated steel webs. The increase of concrete strength will greatly reduce the ductility of the beam.
Table 5. Calculated values of beams with different concrete strength.

\begin{tabular}{|c|c|c|c|c|}
\hline $\begin{array}{c}\text { Name of } \\
\text { beam }\end{array}$ & $\begin{array}{c}\text { Concrete cube } \\
\text { Strength } \\
(\mathrm{MPa})\end{array}$ & $\begin{array}{c}\text { Cracking } \\
\text { Load } \\
(\mathrm{kN})\end{array}$ & $\begin{array}{c}\text { Ultimate } \\
\text { load/ } \\
\text { cracking load }\end{array}$ & $\begin{array}{c}\text { Ultimate } \\
\text { load } \\
(\mathrm{kN})\end{array}$ \\
\hline A & 40 & 32.45 & 5.32 & 172.65 \\
\hline D1 & 60 & 48.68 & 3.95 & 192.16 \\
\hline D2 & 80 & 57.80 & 3.40 & 196.55 \\
\hline $\begin{array}{c}\text { Name of } \\
\text { beam }\end{array}$ & $\begin{array}{c}\text { Ultimate stress } \\
\text { increments } \\
(\mathrm{MPa})\end{array}$ & $\begin{array}{c}\text { Ultimate mid- } \\
\text { spandeflection } \\
(\mathrm{mm})\end{array}$ & $\begin{array}{c}\text { Ultimate } \\
\text { strain of } \\
\text { tensile } \\
\text { reinforcement }\end{array}$ & $\begin{array}{c}\text { Ultimate } \\
\text { strain of } \\
\text { top edge } \\
\text { concrete }\end{array}$ \\
\hline A & 443.04 & 22.35 & 0.0099 & 0.0022 \\
\hline D1 & 455.43 & 22.19 & 0.0100 & 0.0019 \\
\hline D2 & 484.18 & 22.69 & 0.0100 & 0.0017 \\
\hline
\end{tabular}

\subsection{Effective prestress}

Varying the effective prestress of beam A to $323 \mathrm{MPa}$ and 968.9MPa respectively and keeping other parameters unchanged, two beams named E1, E2 can be got and their calculated results are listed in Table 6 . It can be seen from Table 6 that with the increase of effective prestress, the ultimate stress increments of external tendons and the ratio of the ultimate load to the cracking load decrease all along. The ultimate mid-span deflection keeps almost unchanged. The ultimate load increases all along.

When the effective prestress increases $100 \%$, the ultimate stress increments decrease $2 \%$. The ultimate midspan deflection increases by $2 \%$. The ultimate load increases $13 \%$. The ratio of the ultimate load to the cracking load decreases $30 \%$. The effective prestress has some influence on mechanical properties of externally PC beam with corrugated steel webs. The increase of effective prestress will greatly reduce the ductility of the beam.

Table 6. Calculated values of beams with different concrete strength.

\begin{tabular}{|c|c|c|c|c|}
\hline $\begin{array}{c}\text { Name of } \\
\text { beam }\end{array}$ & $\begin{array}{c}\text { Effective } \\
\text { prestress } \\
(\mathrm{MPa})\end{array}$ & $\begin{array}{c}\text { Cracking } \\
\text { Load } \\
(\mathrm{kN})\end{array}$ & $\begin{array}{c}\text { Ultimate } \\
\text { load/ } \\
\text { cracking load }\end{array}$ & $\begin{array}{c}\text { Ultimate } \\
\text { load } \\
(\mathrm{kN})\end{array}$ \\
\hline E1 & 323.0 & 20.94 & 7.88 & 165.03 \\
\hline A & 645.9 & 32.45 & 5.32 & 172.65 \\
\hline E2 & 968.9 & 63.00 & 3.32 & 209.24 \\
\hline $\begin{array}{c}\text { Name of } \\
\text { beam }\end{array}$ & $\begin{array}{c}\text { Ultimate stress } \\
\text { increments } \\
(\mathrm{MPa})\end{array}$ & $\begin{array}{c}\text { Ultimate mid- } \\
\text { span } \\
\text { deflection } \\
(\mathrm{mm})\end{array}$ & $\begin{array}{c}\text { Ultimate } \\
\text { strain of } \\
\text { tensile } \\
\text { reinforcement }\end{array}$ & $\begin{array}{c}\text { Ultimate } \\
\text { strain of } \\
\text { top edge } \\
\text { concrete }\end{array}$ \\
\hline E1 & 449.16 & 22.02 & 0.0100 & 0.0020 \\
\hline A & 443.04 & 22.35 & 0.0099 & 0.0022 \\
\hline E2 & 432.36 & 22.90 & 0.0100 & 0.0025 \\
\hline
\end{tabular}

In summary, the effects of these four parameters on the bending performance of externally PC beam with corrugated steel webs in descending order are: tension steel area, concrete strength, effective prestress, compression steel area.

\section{Conclusions}

(1) Applying the compiled computer program based on moment-curvature to analyze the bending performance of simply supported externally PC beam with corrugated steel webs is feasible. 
(2) The tension steel area affected the bending performance of simply supported externally PC beam with corrugated steel webs mostly, followed by the concrete strength and effective prestress. The compression steel area has the minimal impact on the bending performance of this beam.

\section{References}

1. M. Cheyrezy and J. Combault, Composite bridges with corrugated steel webs -achievements and prospects,IABSE Symposium on Mixed Structures including New Materials, Brussels, 1990, pp. 479484.

2. C. Machimdamrong, E. Watanabe and T. Ustunomiya, Analysis of corrugated steel web girders by an efficient beam bending theory, Structural Engineering, 2004, 21(2), pp. 131s-142s.

3. J.F. Bariant, T. Utsunomiya and E. Watanabe, Elasto-plastic analysis of PC girder with corrugated steel web by an efficient beam theory, Structural Engineering, 2006, 23(2), pp. 257s-268s.

4. X.C. Chen, F.T.K. Au, Z.Z. Bai, Z.H. Li and R.J. Jiang, Flexural ductility of reinforced and prestressed concrete sections with corrugated steel webs, Computers and Concrete, 2015, 16(4), pp. 625-642.
5. H.J. LI, S Wan and J.S. Ye, Structure Features of Prestressed Concrete Box girder with Corrugated Steel Webs, Journal of Highway and Transportation Research and Development, 2002, 19(3), pp. 54-57.

6. R Luo and B Edlund, Shear Capacity of Plate Girders with Trapezoidally Corrugated Webs, Thinwalled Structures, 1996, 26(1), pp. 19-44.

7. R. P. Johnson and J. Cafolla, Corrugated webs in plate girders for bridges. Proceedings of the ICE Structures and Buildings, 1997, 122(2),pp. 157-164.

8. Y.Q Liu, Steel concre Hybrid Bridge (China Communications Press, Beijing, China, 2005).

9. M. Elgaaly, A. Seshadri and R.W. Hamilton, Bending Strength of Steel Beams with Corrugated Webs, Journal of Structural Engineering, 1997, 123(6), pp. 772-782.

10. J.Y. Song, S.R. ZHANG and Z.L. Wang, Whole Bending Process of Externally Prestressed Composite Beam with Corrugated Steel Webs, Journal of Harbin Institute of Technology University, 2003, 35(5), pp. 590-593.

11. J.Y. Song, Mechanical Properties of Externally Prestressed Composite Beam with Corrugated Steel Webs, Harbin Institute of Technology, Harbin, China, 2003. 